\title{
Analysis of Tribo-corrosion Properties of MAO/DLC Coatings Using a Duplex Process on $\mathrm{Ti}_{6} \mathbf{A l}_{\mathbf{4}} \mathrm{V}$ Alloys
}

\author{
Ebru Emine Sukuroglu ${ }^{1} \cdot$ Yasar Totik $^{2} \cdot$ Ersin Arslan $^{2} \cdot$ Ihsan Efeoglu $^{2}$
}

Received: 31 March 2015/Revised: 11 June 2015/ Accepted: 8 July 2015/Published online: 22 July 2015

(c) Springer International Publishing AG 2015

\begin{abstract}
In recent years, various technologies have been increasingly investigated for the surface modification of $\mathrm{Ti}$ and Ti alloys. Microarc oxidation (MAO) is one of the effective techniques to improve surface properties. However, it has some disadvantages for sliding wear applications and/or aggressive environments. In this study, the combined MAO and closed field unbalanced magnetron sputtering process was used to deposit duplex MAO/diamond-like carbon (DLC) coatings on $\mathrm{Ti}_{6} \mathrm{Al}_{4} \mathrm{~V}$ alloy. Analysis of the microstructures, morphology, and crystallographic structure were performed by using a SEM, Raman, and XRD. The wear, corrosion, and tribo-corrosion properties of the coatings were investigated using the pinon-disk wear test, potentiodynamic polarization test, and combining tribo-corrosion test unit, respectively. The results of this study have shown that duplex MAO/DLC coatings exhibit better wear, corrosion, and tribo-corrosion properties than the DLC or MAO monolayer on $\mathrm{Ti}_{6} \mathrm{Al}_{4} \mathrm{~V}$ alloy substrate. MAO/DLC coatings exhibited dense structure, lower coefficient of friction and corrosion current density, and higher tribo-corrosion resistance. The results have also shown that MAO/DLC duplex coatings on $\mathrm{Ti}_{6-}$ $\mathrm{Al}_{4} \mathrm{~V}$ substrates increased the tribo-corrosion resistance by acting as a barrier layer.
\end{abstract}

Ebru Emine Sukuroglu

eesukuroglu@gumushane.edu.tr

1 Department of Mechanical Engineering, Faculty of Engineering, Gumushane University, Gumushane, Turkey

2 Department of Mechanical Engineering, Faculty of Engineering, Ataturk University, Erzurum, Turkey
Keywords Microarc oxidation process - Closed field unbalanced magnetron sputtering process - DLC coatings . Wear resistance . Corrosion resistance and tribo-corrosion resistance

\section{Introduction}

Light materials are very attractive because of their low specific weight, even though using them in the industrial applications has not expanded as hoped. This is because they have weak mechanical and tribological properties under overload and low corrosion resistance in overly aggressive environments. Because of these disadvantages, many studies have been focused on solving surface problems of these metals. Hard coatings that are produced in parallel with the developments in surface engineering methods have met the friction and wear resistance substantially. Coatings such as TiN, TiC, c-BN, TiN/VN, TiN/NbN etc., have higher melting point, hardness, wear resistance, electrical and thermal conductivity, and chemical insensitivity compared to acids and alkalis [1-4]. Because of these superior properties, their wear, friction, and corrosion resistance can be increased at high speeds, temperatures, and overload conditions without damage [5-7]. For these reasons in recent years, many studies have focused on the diamond-like carbon (DLC) coatings [8-10].

DLC coatings are generally deposited on the materials' surface using electro-plating, laser coating [11], pulsed electrode plating, thermal spraying [12], chemical vapor deposition (CVD), physical vapor deposition (PVD) [1315], electron bombardment, and evaporator [12, 16-18] methods. Their resistances according to temperature, friction, wear, and corrosion effects depend on the variety of coating methods and coating parameters [18-20]. In the 
literature, PVD method has been generally used for the DLC coating and the most commonly used magnetic field sputtering method has been identified [20-23]. Unbalanced magnetron sputtering method is one of the PVD methods. In this method, the ion bombardment during film growth offers more flexibility, better control, and further improvement of the coating properties [24, 25]. However, hard carbon-based coatings such as DLC, on the use of light metals titanium and titanium alloys are very limited [26, 27]. This is because the substrate is lower than the hard coating having a modulus of elasticity and the hardness is due to occurrence of mechanical incompatibility. Therefore, recently, the studies have been about the DLC coating of titanium and its alloys to eliminate the mechanical mismatch.

There has been a tendency toward the method known as the duplex surface process for the enhancement of surface features of substrates, especially with a protective coating [28]. The duplex surface process is the combination of two surface enhancement methods to compensate the features that cannot be obtained from a single surface enhancement method [29-31].

Recently, an electrochemical process that the microarc oxidation (MAO), also known as the plasma electrolytic oxidation (PEO) process, has been applied on the light alloy to extend this mismatch between the substrate and coating and also improve the surface properties before the DLC coating process.

MAO or PEO process is an electrochemical surface treatment that is performed in a plasma environment. The use of MAO has been increasing day by day to improve wear resistance, corrosion resistance, and load carrying capacity of the Titanium surface and its alloys [32-35]. A ceramic oxide layer, which is relatively thick (approximately $150 \mu \mathrm{m}$ ), hard, high wear resistant, and with excellent adhesion to the substrate, is able to achieve success by using this method.

This study focused on the purpose of improving the surface properties of $\mathrm{Ti}_{6} \mathrm{Al}_{4} \mathrm{~V}$ alloy by DLC coating using the CFUBMS method and by the growth of an intermediate oxide layer for minimizing the mechanical mismatch between the substrate and coating using the MAO method. Structural, mechanical, wear, corrosion, and tribo-corrosion behaviors of coatings were analyzed with XRD, Raman spectroscopy, SEM, 3D surface profilometer, nano-hardness tester, pin-on-disk, potentiostat, and tribo-corrosion cell.

\section{Materials and Methods}

$\mathrm{Ti}_{6} \mathrm{Al}_{4} \mathrm{~V}\left(R_{\mathrm{a}}=0.1 \mu \mathrm{m}\right)$ was used as the substrate material for the duplex deposition process of MAO/DLC. Chemical composition of the $\mathrm{Ti}_{6} \mathrm{Al}_{4} \mathrm{~V}$ (Grade 5) substrate was $6 \mathrm{wt} \%$ $\mathrm{Al}, 4 \mathrm{wt} \% \mathrm{~V}, 0.16 \mathrm{wt} \% \mathrm{Fe}, 0.01 \mathrm{wt} \% \mathrm{C}, 0.01 \mathrm{wt} \% \mathrm{~N}$,
$0.07 \mathrm{wt} \% \mathrm{O}, 0.006 \mathrm{wt} \% \mathrm{H}$, and Ti balance. Preparation of the sample surfaces was presented in detail in the previous study [23]. First, $\mathrm{TiO}_{2}$ coatings were prepared on the $\mathrm{Ti}_{6}$ $\mathrm{Al}_{4} \mathrm{~V}$ alloy using MAO. The MAO treatment of the titanium alloys was performed in the MAO-15 system designed and built by Plasma Technology Ltd-Hong Kong as shown in Fig. 1. The MAO parameters have been selected based on the results of our previous study [23]. The bipolar mode at a constant potential of $+450 /-150 \mathrm{~V}$ was applied to the substrate for $15 \mathrm{~min}$. Secondly, DLC coatings were prepared by a closed field unbalanced magnetron sputtering system (CFUBMS) on Ti6Al4V. DLC coatings were deposited by non-reactive pulsed magnetron sputtering processes in the Teer Coating System-UK as shown in Fig. 2. The DLC coating parameters have been selected based on the results of our previous study [23]. Deposition conditions selected for the deposition of DLC were a substrate bias voltage of $-100 \mathrm{~V}$, a sputtering pressure of $0.3 \mathrm{~Pa}$, and a frequency of $250 \mathrm{~Hz}$ in the Ar atmosphere. Analysis of the characterization tests as SEM, RAMAN, and XRD was performed in our previous study [23].

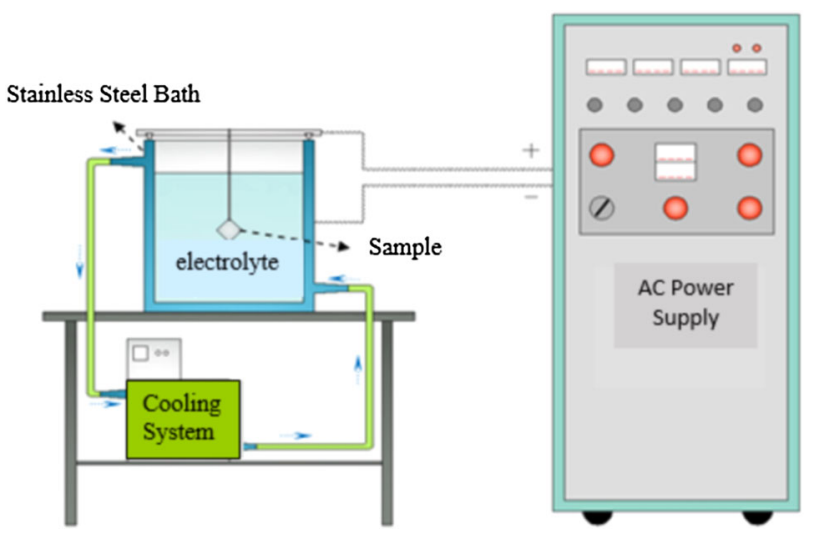

Fig. 1 MAO system

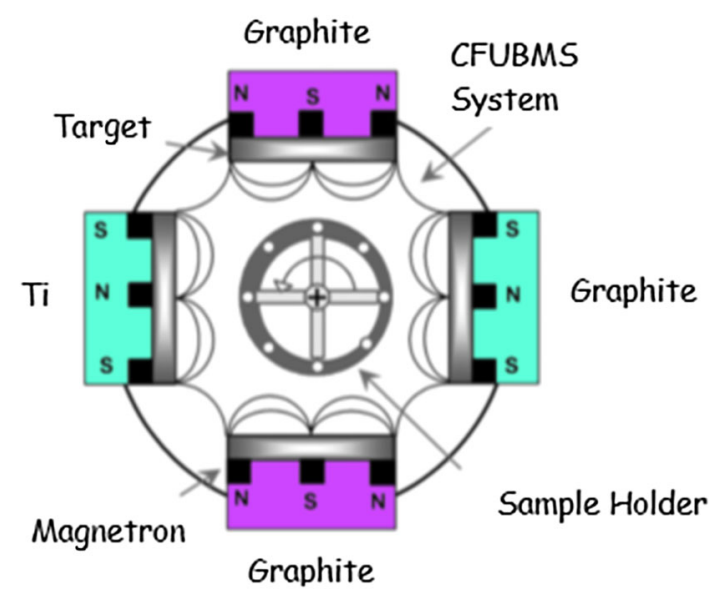

Fig. 2 CFUBMS system 
The pin-on-disk tribotester (Teer-POD2) was used to determine the tribological properties of coatings deposited on the $\mathrm{Ti}_{6} \mathrm{Al}_{4} \mathrm{~V}$ substrate $\left(R_{\mathrm{a}}=0.1 \mu \mathrm{m}\right)$, using a $5 \mathrm{~mm}$ diameter $\mathrm{Al}_{2} \mathrm{O}_{3}$ ball as the pin. Unlubricated wear tests with a sliding time of $600 \mathrm{~s}$ were carried out at room temperature $\left(\approx 18^{\circ} \mathrm{C}\right)$ with a relative humidity of approximately $50 \%$, a sliding speed of $100 \mathrm{rev} / \mathrm{min}$, a normal load of $2 \mathrm{~N}$, and a wear track diameter of $5 \mathrm{~mm}$. The wear rate loss was determined using the profilometry of cross-sectional area of wear tracks by a Ambios XP-2 3D profilometer. The worn surface morphologies were then examined using Jeol-6400 SEM.

Corrosion experiments including potentiodynamic polarization tests were performed using a computer controlled Versastat3 Potentiostat. A standard three-electrode cell with platinum electrode as an auxiliary electrode, saturated $\mathrm{Ag} / \mathrm{AgCl}$ electrode as a reference electrode, and samples as working electrode was used. Samples (with $1 \mathrm{~cm}^{2}$ exposed surface area) were immersed for $60 \mathrm{~min}$ in the electrolyte to reach a steady-state OCP value and then the electrochemical test was carried out in a solution of $3.5 \% \mathrm{NaCl}$ at $37 \pm 1{ }^{\circ} \mathrm{C}$. The potentiodynamic polarization studies were carried out in the range of $-250 \mathrm{mV}$ (vs. OCP) to $+1000 \mathrm{mV}$ with the scan rate of $1 \mathrm{mV} / \mathrm{s}$.

Tribo-corrosion behaviors of the uncoated, MAOcoated, DLC-coated, and Duplex (MAO/DLC)-coated samples were evaluated by using a tribo-electrochemical technique with a $\mathrm{Al}_{2} \mathrm{O}_{3}$ ball $(\varphi=5 \mathrm{~mm})$ as counter material as shown in Fig. 3. Tests were carried out at a normal load of $2 \mathrm{~N}$. Experiments were performed in $3.5 \%$ $\mathrm{NaCl}$ solution at $37 \pm 1{ }^{\circ} \mathrm{C}$ with $1 \mathrm{~cm}^{2}$ exposed surface area. Variation of OCP was recorded using a Potentiostat, where a three-electrode system, similar to electrochemical tests, was used. Before sliding, specimens were exposed to electrolyte for $3600 \mathrm{~s}$ in order to reach the stable potential. The OCP was recorded $600 \mathrm{~s}$ before, $600 \mathrm{~s}$ during, and 600 or $400 \mathrm{~s}$ after the sliding. The worn surfaces were rinsed with distilled water to remove corrosion products and wear debris.

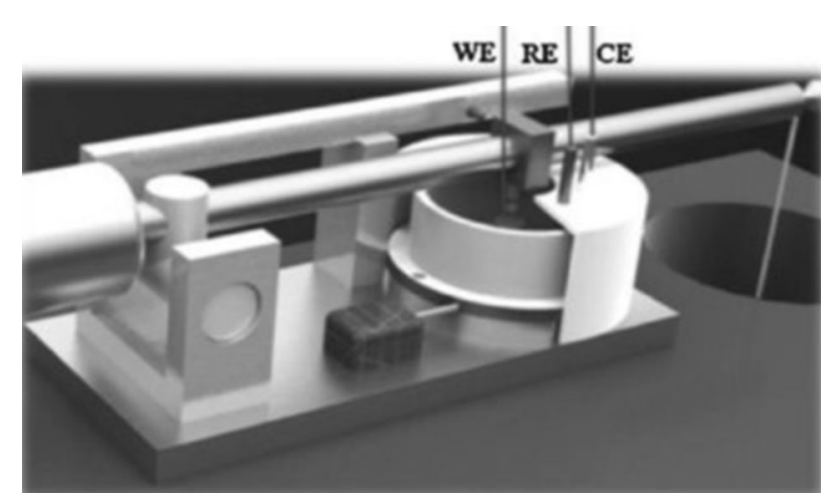

Fig. 3 The tribo-corrosion test system

\section{Results and Discussion}

\subsection{Results of Coating Characterization Test}

The surface morphologies that were achieved after MAO on $\mathrm{Ti}_{6} \mathrm{Al}_{4} \mathrm{~V}$ alloys and the cross-section images are presented in Fig. $4 \mathrm{a}$, b. Depending on the micro-discharge phenomenon resulting from the nature of MAO process, it has been seen that the coatings on the substrate have a rough surface, many grains of different sizes, and numerous circular micropores at the tip of some large-sized grains [23]. The regional melting that takes place during the coating process and the circular path of the solidification trail that follows this process causes the pores that are formed in the coating to achieve an almost circular geometry. The MAO process depends on the conventional anodic oxidation of metals and alloys resting in aqueous electrolytic solution under additional plasma discharge conditions that form after the polarization potential exceed the critical value. This discharge event leads to high pressure and high temperatures localized within the discharge channel that gives shape to coating materials. Therefore, the melted products are rapidly cooled by the electrolyte; whereas, solidification is achieved inside the channels and the channels start to fill up. However, shallow pores are formed at the external opening of the channels as a result of the products, which are formed as a result of melting fill-in the channels insufficiently and the outward path of the emerging gases [2426]. The pores at the sizes of micron-submicron and uniform/non-uniform pores distribution are obtained depending on the coating parameters grown on $\mathrm{Cp}-\mathrm{Ti}$ alloy. The reason of the differences between uniform and non-uniform distributions of this pores structure is suggested to be caused by the local melting inside the arc channels and the diffusion of the molten material $[27,28]$. As known, the MAO oxide films are composed of three distinct regions. The first region is called as transition region. This region is between the coating and the substrate; moreover, it has very high adhesion properties [23]. The second region is called functional main region. The thickness depends on this region directly and the last region is called as loose region. When the functional main region and the loose region are compared with each other, the loose region has more pores than the main region [36-38]. The oxide film has a thicker and greater homogeneous thickness of approximately $5 \mu \mathrm{m}$, and contains smaller porosity. Figure $4 \mathrm{c}, \mathrm{d}$ also shows the cross sections of the DLC and duplex (MAO/DLC) coating on the $\mathrm{Ti}_{6} \mathrm{Al}_{4} \mathrm{~V}$ substrate. As shown in Fig. $4 \mathrm{c}$, the DLC coatings deposited on the $\mathrm{Ti}_{6} \mathrm{Al}_{4} \mathrm{~V}$ substrate had a thickness of around $6 \mu \mathrm{m}$. The DLC films were uniform, compact, smooth, and dense. The dense microstructure is an important factor for the hardness. This causes an increase in wear 

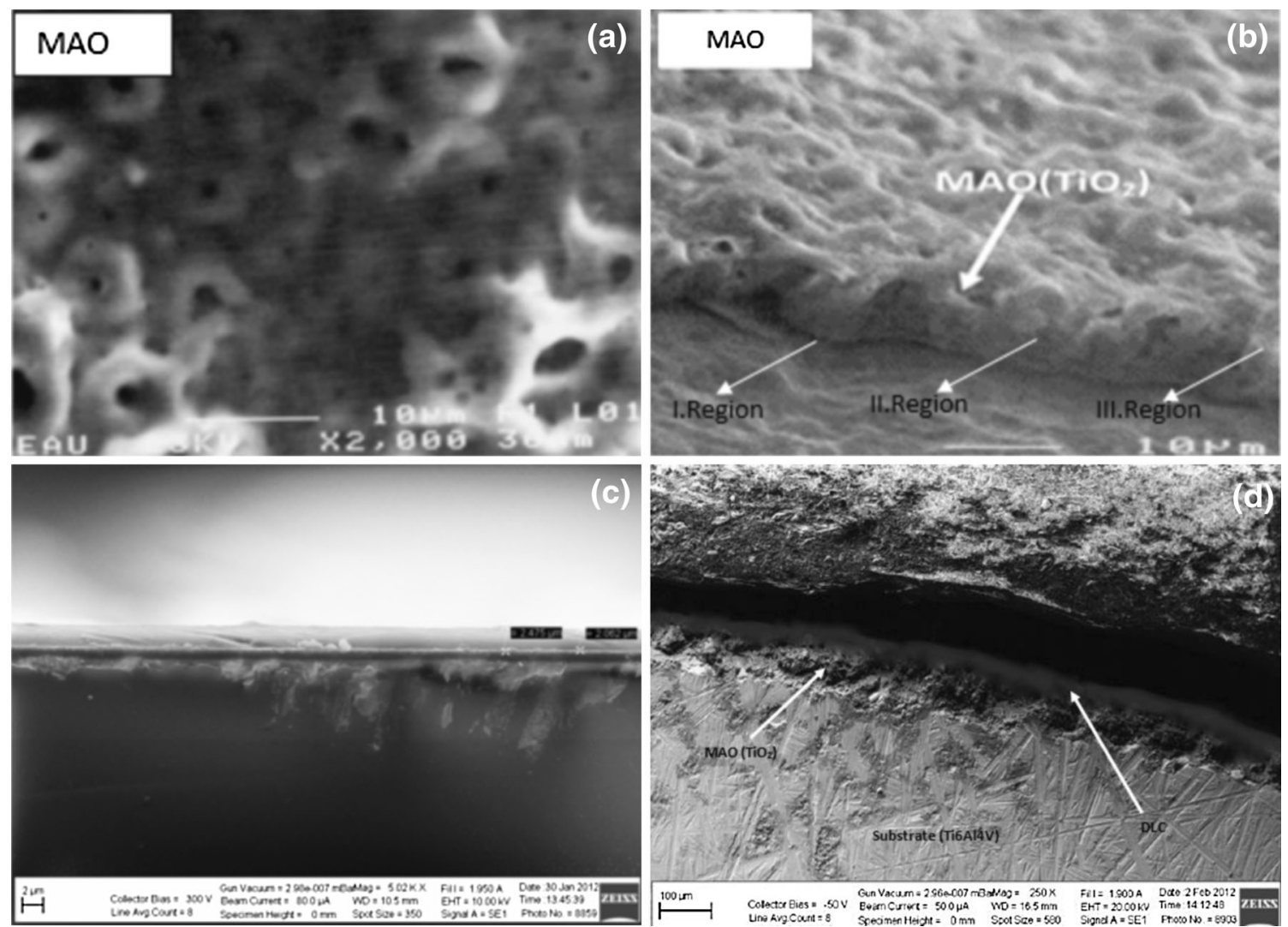

Fig. 4 The surface morphologies and the cross-section images for coated samples a, b MAO coated, $\mathbf{c}$ DLC coated, and d Duplex (MAO/DLC) coated

resistance [39, 40]. Duplex coatings were uniform, compact, smooth, and dense as the DLC films that were directly coated onto the substrate. Because of these, it is thought that the uniform, compact, smooth, and dense surface properties depend on the frequency value. In addition, the cross section of the duplex process in Fig. 4d shows that the interfaces of the $\mathrm{Ti}_{6} \mathrm{Al}_{4} \mathrm{~V}$ substrate/MAO and DLC coatings were metallurgically bonded clearly. However, the top layer has a roughness surface, because the DLC coating was deposited on the MAO coatings and was not uniformed due to the surface roughness of the interface. Because of this situation, it is thought to arise from columnar growing of the DLC coatings. This is further supported by studies in the literature [23].

The XRD patterns of the coatings grown by MAO are given in Fig. 5. Crystal structures of the raised $\mathrm{TiO}_{2}$ film grown by the MAO process were given in detail in our previous study [23]. The phase analysis of DLC coatings and MAO/DLC duplex coatings could not be detected by XRD due to the presence of carbon amorphous stated in the structure. Figure $6 a, b$ shows the Raman spectrum of the coatings. The sharp Raman peaks were determined on the DLC and $\mathrm{MAO} / \mathrm{DLC}$ duplex coatings at approximately $1570-1580 \mathrm{~cm}^{-1}$, respectively. The expanding peaks were determined on the DLC and MAO/DLC duplex coatings at approximately 1380 and $1330 \mathrm{~cm}^{-1}$, respectively. The intensity rate of the $D$ peak to the intensity of the $G$ peak $(I D / I G)$ as well as the relative presence of $s p^{2}$ (graphite) and $s p^{3}$ (diamond) bonds $\left(s p^{2} / s p^{3}\right)$ was evaluated. Pang et al. illustrate that decreasing this ratio was increasing the amount of $s p^{3}$ structure. It is observed by the increase in peak width and density of the DLC coatings structure. In addition, in the literature, it is indicated that the substrate temperature, the gases rate, and pressure are important on $s p^{2} / s p^{3}$ ratio [41-43]. This result is nearly the same with our previous study [23].

\subsection{Results of Nano-hardness Test}

Figure 7 shows the hardness rate of the $\mathrm{Ti}_{6} \mathrm{Al}_{4} \mathrm{~V}$ substrate, MAO coating, DLC coating, and MAO/DLC duplex coatings. Because of the pores and roughness of the surface, the nano-hardness measurements were obtained from the crosssections area. The average nano-hardness of the $\mathrm{Ti}_{6} \mathrm{Al}_{4} \mathrm{~V}$ substrate was $4 \mathrm{GPa}$. After the MAO and CFUBMS process on the $\mathrm{Ti}_{6} \mathrm{Al}_{4} \mathrm{~V}$ substrate, the nano-hardness values of MAO and DLC coating were obtained as approximately 8 and 19 $\mathrm{GPa}$, respectively. The results show that high frequency 
Fig. 5 The XRD patterns of the coatings grown by MAO
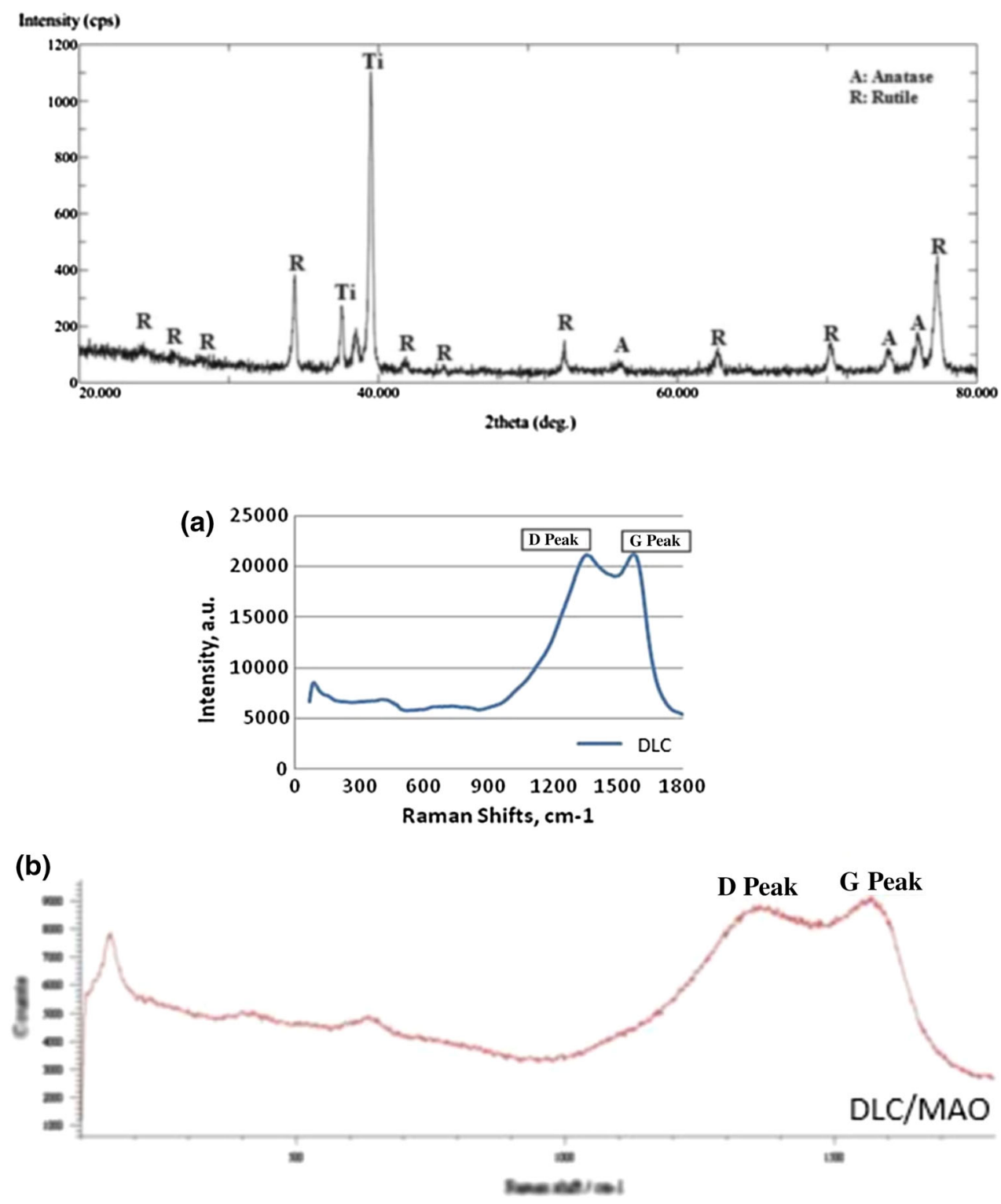

Fig. 6 The Raman patterns of the coatings a DLC coated and b duplex (MAO/DLC) coated

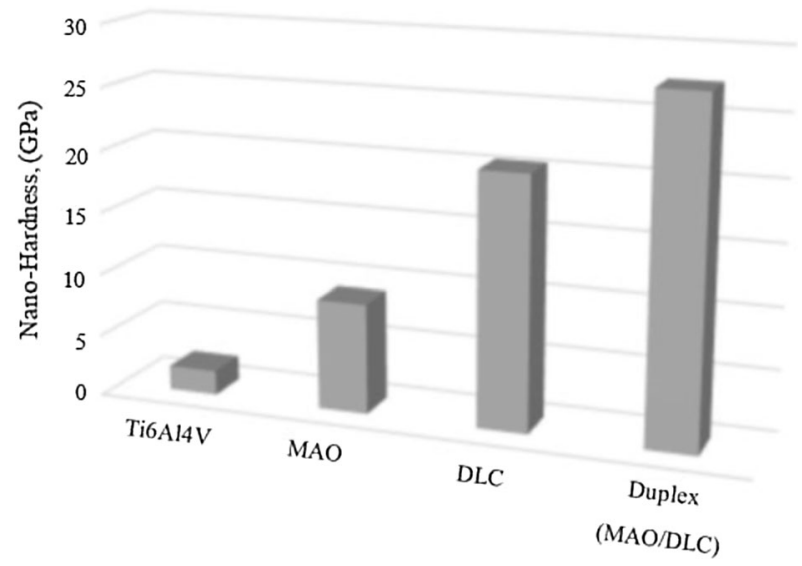

Fig. 7 The hardness volume of the $\mathrm{Ti}_{6} \mathrm{Al}_{4} \mathrm{~V}$ substrate, MAO coating, DLC coating, and duplex (MAO/DLC) coatings value caused smaller diameter of pores and more uniform structure. In addition, the duty cycle value was low. The dense, brittle, and rough structure did not grow on the topmost surface of the coating because of this low value. This situation has led to an increase in hardness. In addition, as a result of XRD of the stable rutile phase, the highest densities were determined. Rutile phase is the most important parameter for increasing the hardness [23].

When the DLC coatings are growing, the substrate voltage is the most important parameter for the hardness. Because the dense and hard coatings depend on the high substrate voltage in the CFUBMS system, high substrate voltage causes high compressive stress, and high compressive stress increases the hardness of coatings. The second factor is the frequency. The coating method of ionized particles increases by the effect of the flow 
frequency. Increased ionization permits low deposition pressure [44]. When the DLC and MAO/DLC duplex coatings grow, the high substrate voltage and high frequency are applied. The high substrate voltage caused high compressive stress and high frequency increased the ionized particles flow acceleration, and thus these two parameters' sputtering pressure to be effective considering the high hardness of DLC, MAO/DLC duplex coating growth is provided. Moreover, higher target current causes the rising, the transmission of the $\mathrm{C}$ atoms to the substrate and increased the hardness of the coatings. In other studies, $s p^{2} / s p^{3}$ ratio would increase with the increasing coating density and therefore it was stated that the hardness was increased [45-47]. This result is supported by Raman graphics in Fig. 6. The MAO/DLC duplex coatings that created the DLC coating had a final coating on the surface of the intermediate layer of the coating containing MAO. When the MAO/DLC duplex coatings are compared with the DLC coating and MAO coatings, the duplex coating hardness values were found much higher. It is thought that the DLC coating was affected by hardness from hard MAO coating. While each surface process advanced nano-hardness of the $\mathrm{Ti}_{6} \mathrm{Al}_{4} \mathrm{~V}$ substrate, the highest nano-hardness of $28 \mathrm{GPa}$ was obtained from the duplex MAO/DLC coatings.

\subsection{Results of Corrosion Test}

The polarization curves indicate that the solutions influenced the corrosion resistance of the coatings. The $I_{\text {corr }}$ and $E_{\text {corr }}$ values were determined using the Tafel chart. The lowest corrosion current and the highest corrosion potential values are important for the determination of the corrosion resistance. According to the experimental results, the samples, which were MAO/DLC duplex coated, showed the highest corrosion potential and the lowest corrosion current. The coating constituted a barrier between the substrate and the corrosion environment. The polarization curves of the MAO, $\mathrm{DLC}$, and MAO/DLC duplex process are given in Fig. 8. The oxidized sample has a more porous structure because of the use of MAO $\left(\mathrm{TiO}_{2}\right)$ surfaces. The corrosion behavior of the oxidized specimens changed with the uniformity of the coating, surface roughness, and the number and the dimension of the pores on the surface [23, 48]. The best surface morphology was obtained from the samples that were MAO/ DLC duplex coated. The samples that are duplex coated have a dense and uniform structure, with no pore and thus, the corrosion current density was lower. On the MAO-coated samples, the number of the corroded regions increases, because the contact areas between the porous oxide layer and the solution grow. Deep splits and the structural discontinuity on the surface of the materials, which have a high surface roughness, expedite the diffusion of the $\mathrm{Cl}^{-}$ions into the coating and decrease the corrosion resistance $[49,50]$.

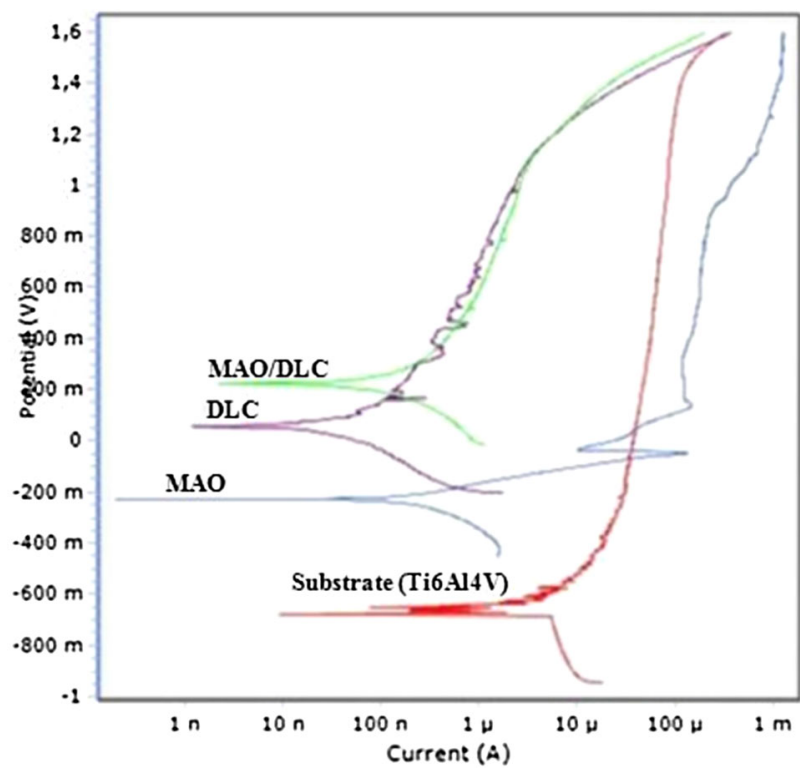

Fig. 8 Polarization curve of the coated and uncoated samples

The coatings that are grown on the substrate improve the corrosion resistance of the substrate by creating a barrier by passing the $\mathrm{Cl}^{-}$ions in solution or in the environment [51-53]. It is found that the DLC coating and MAO/DLC duplex coatings exhibited passivation tendency behavior; they have high corrosion potential values and the low corrosion current values. The corrosion current densities $\left(I_{\text {corr }}\right)$ are $5 \times 10^{-6} \mathrm{~A} / \mathrm{cm}^{2}$ for the $\mathrm{Ti}_{6} \mathrm{Al}_{4} \mathrm{~V}$ substrate, $10 \times 10^{-9}$, $1 \times 10^{-9}$, and $5 \times 10^{-9} \mathrm{~A} / \mathrm{cm}^{2}$ for the coated samples, MAO, DLC, and MAO/DLC, respectively. The corrosion potentials $\left(E_{\text {corr }}\right)$ are $-700 \mathrm{mV}$ for the $\mathrm{Ti}_{6} \mathrm{Al}_{4} \mathrm{~V}$ substrate, $-200,50$, and $250 \mathrm{mV}$ for the coated samples MAO, DLC, and MAO/DLC, respectively. It was observed that the corrosion potential of the coating rose to more respectable values as compared to the substrate. The increase in the corrosion resistance on the DLC coating was explained by electron reduction in the literature [54]. In their study, they explained that the diamond structure of the DLC had low conductivity. The increase in the insulator of the DLC coatings structure caused a decrease in the electron conductivity and thus the corrosion resistance of the surface has been improved [54]. The final surface on the substrate is DLC coatings. Therefore, the increase in the corrosion resistance can be associated with the decrease in the electron conductivity. This situation is supported by the $s p^{2} / s p^{3}$ ratio in the structure. It is detected by the Raman analysis in Fig. 6 .

\subsection{Results of Wear Test}

The tribological tests of the MAO, DLC, and MAO/DLC duplex process coatings were performed at room temperature. Figure 9 shows the relationship between the friction 
Fig. 9 Friction coefficients and wear scar SEM images of samples. a Uncoated, b MAO coated, c DLC coated, and d duplex (MAO/DLC) coated
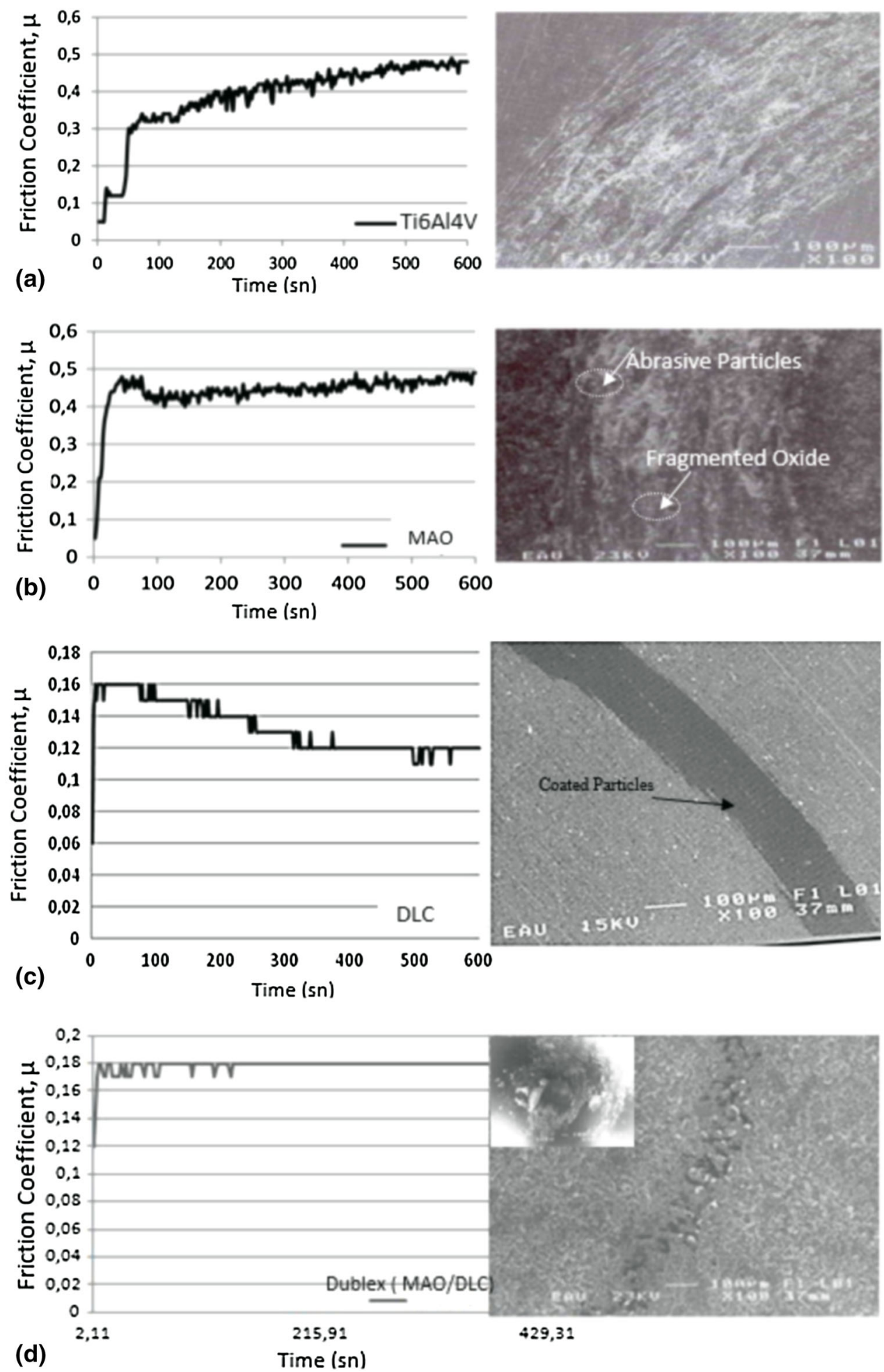

coefficient and the time for the MAO, DLC, and the MAO/ DLC duplex process. After the tribological tests, the wear tracks of each sample were also observed using a SEM, as seen in Fig. 9a-d. At the start of the dry tribological test of the MAO coating, the friction coefficient $(\mu)$ against the counter face $\left(\mathrm{Al}_{2} \mathrm{O}_{3}\right.$ ball) is gradually increased to $160 \mathrm{~s}$. At the initial stage, the increase in the friction coefficient is resulted from the abrasive effect of the hard $\mathrm{TiO}_{2}$ phases. The friction coefficient values began to decrease after that. The reason of the decrease in the friction coefficient of the 
(a)
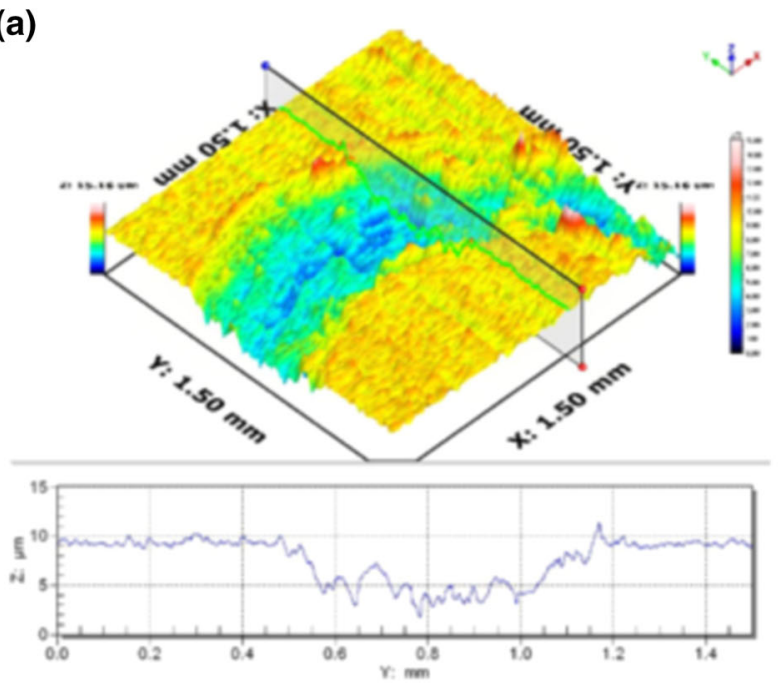

(c)
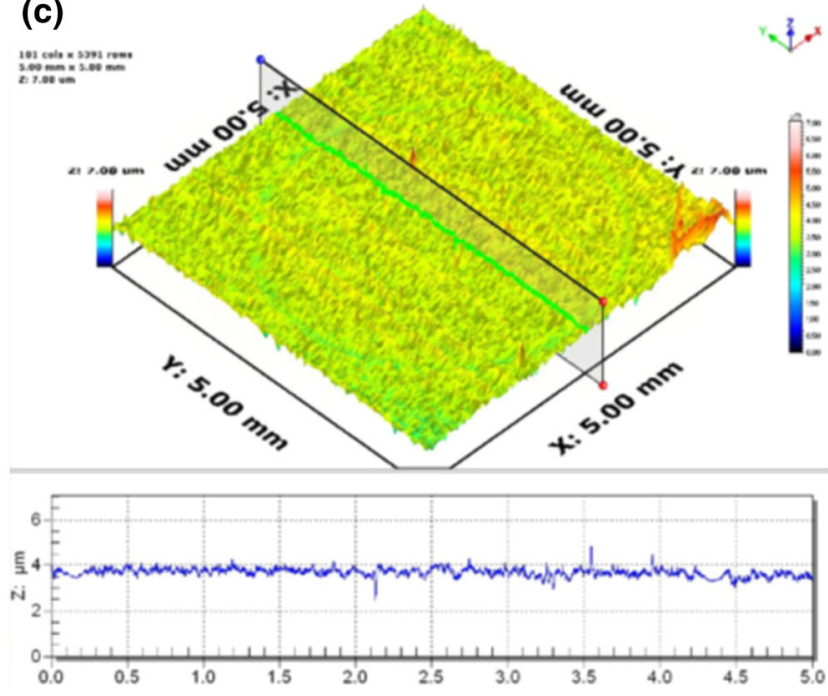

(b)
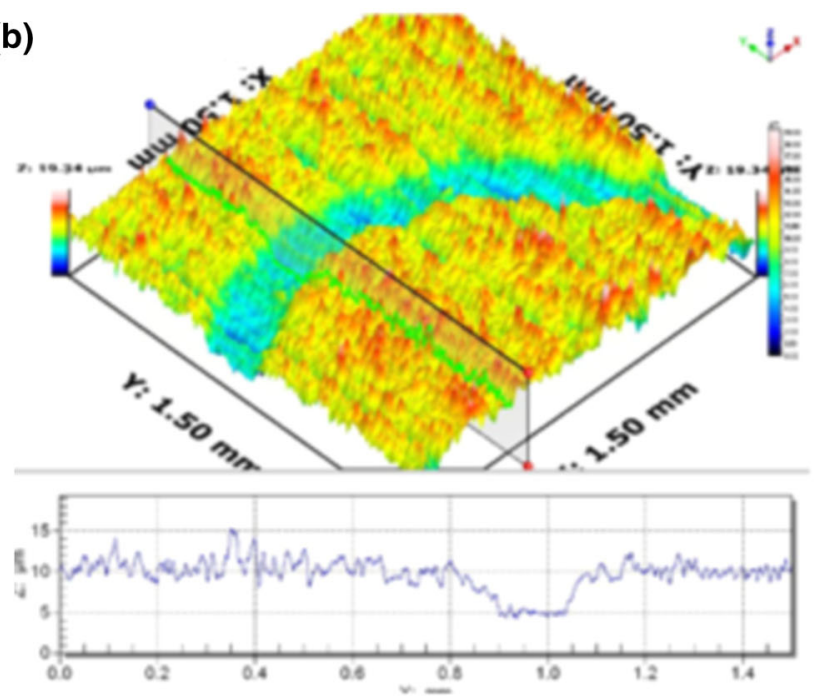

(d)
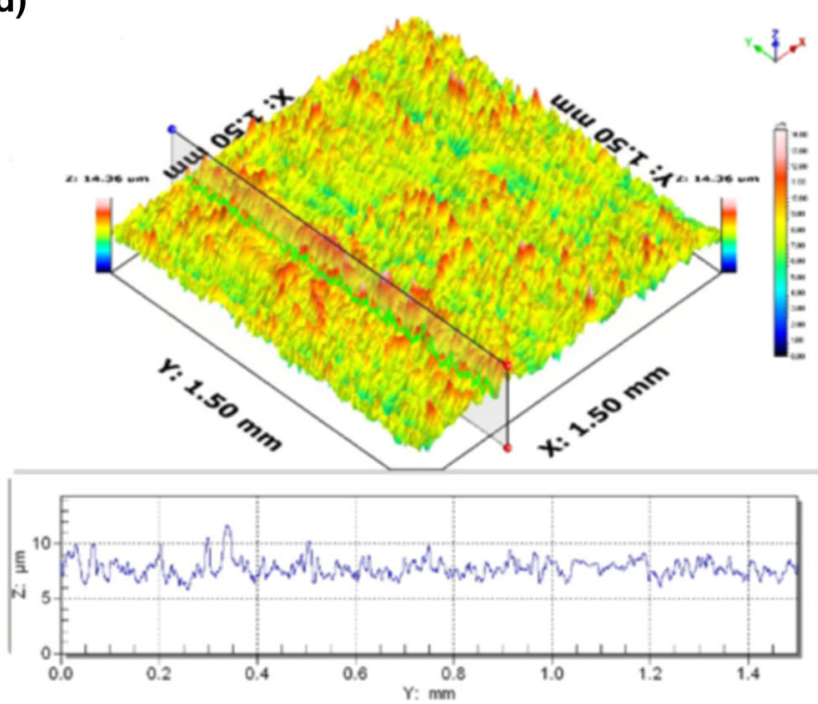

Fig. 10 3D images of samples a uncoated, b MAO coated, c DLC coated, and $\mathbf{d}$ duplex (MAO/DLC) coated

$\mathrm{Ti}_{6} \mathrm{Al}_{4} \mathrm{~V}$ can be explained with the re-modification of the surface topography. As shown in Fig. 9a, the friction coefficient $(\mu)$ of the substrate was considerably high, approximately $\geq 0.45$, and fluctuated [55]. Figure 10 shows the 3D-images of the wear track. As shown in Fig. 7a, the passive oxide layer separated from the substrate shortly later and caused damage by doing abrasive effects. Figures $9 \mathrm{a}$ and 10a clearly show that the wear track is quite wide and deep.

Figure 9b shows the friction coefficient $(\mu)$-time graph and SEM picture of wear track of the MAO coatings on $\mathrm{Ti}_{6} \mathrm{Al}_{4} \mathrm{~V}$ substrate after the wear test. When the MAOcoated sample and the uncoated sample are compared, it is observed that the friction coefficients of the coated sample stay more stable until the end of the experiment. The MAO-coated samples ranging from around $\mu=0.4$ and
0.5 showed a stable friction coefficient. Overall stable coefficient of friction in the coated sample for around $100 \mathrm{~s}$ after the switch has been initiated, after which the the determination of the time was continued until the end, while maintaining the assay. The reason of the high and unstable coefficient of friction until about $100 \mathrm{~s}$ is the amorphous loose layer of the MAO coatings. Wearing the amorphous loose layer immediately, the layer called the functional main layer occurred and thus it caused the stable friction coefficient. When the results of the XRD and microstructure are associated with the friction coefficienttime graph, it is seen that the less pores and thin amorphous loose layer caused the stable friction coefficient. When the MAO-coated samples are compared with the $\mathrm{Ti}_{6} \mathrm{Al}_{4} \mathrm{~V}$ substrate, it is shown in Fig. 10b that the wear track is narrow and the depth of wear track is low. 
The initial value of the friction coefficient was approximately 0.25 for $15 \mathrm{~s}$, as the friction coefficient and the time graph of DLC coatings deposited on the $\mathrm{Ti}_{6} \mathrm{Al}_{4} \mathrm{~V}$ substrate showed (Fig. 9c). The coefficient friction value dropped suddenly to approximately 0.12 after that and continued to remain stable for $420 \mathrm{~s}$. It is promoted in the literature that the friction accelerated the transformation from $s p^{3}$ to $s p^{2}$ and thus, it created a transfer film on the DLC surface-like graphite and this film participates in lubricant [56-60]. Then the friction coefficient increased abruptly, and the DLC coatings were broken without finalizing the wear test. This situation indicated that the hard DLC coatings deposited on the $\mathrm{Ti}_{6} \mathrm{Al}_{4} \mathrm{~V}$ did not have sufficient load-bearing capacities. The SEM image taken from the edge of the wear track given in Figs. 9c and 10c demonstrates regional cracks in the coating. These cracks are clear indications of the incompatibility of the DLC substrate systems. When the duplex coatings were compared with the DLC coating, no cracks were observed until the end of the test (Figs. 9d, 10d). The wear tracks were very narrow and very thin abrasive particles that were formed at the edge of the tracks. According to this result, it can be deduced that the MAO/DLC duplex coating has better tribological behaviors than the MAO and DLC coatings deposited on the $\mathrm{Ti}_{6} \mathrm{Al}_{4} \mathrm{~V}$ substrate. The MAO intermediate layer improved the load-bearing capacity and tribological properties of the DLC coatings markedly because it decreased the mechanical incompatibility between the soft substrate and hard coating [23].

However, as shown in Fig. 6a, the friction coefficients for duplex MAO/DLC coatings on the $\mathrm{Ti}_{6} \mathrm{Al}_{4} \mathrm{~V}$ substrate remained much more stable at approximately 0.1 . According to the literature, the low friction coefficient of the DLC coatings shows that the friction accelerates the transformation of the $s p^{3}$ to $s p^{2}$ form and it creates the graphite transfer surface form on the DLC surface; and for that reason, it is used as a lubricant [56]. Moreover, the low friction coefficient of DLC coatings shows that the high hardness DLC coatings create lower contact areas between the coating and ball and so it occurs less wear. The results of these studies are in accordance with the literature [23, $51,61]$. In addition, these low friction values show that $\mathrm{C}-$ $\mathrm{C}$ bonds of DLC coatings are broken and the $s p^{3}$ structure turns into $s p^{2}$ structure. This $s p^{2}$ (graphite) structure by serving as a solid lubricant contributes to the formation of the appropriate transfer film [62-64]. When the duplex coatings were compared with the DLC coating, no cracks were observed until the end of the test (Fig. 5d). The wear tracks were very narrow, and very thin abrasive particles were formed at the edge of the tracks. According to this result, it can be deduced that the MAO/DLC duplex coating has better tribological behaviors than the MAO and DLC coatings deposited on the $\mathrm{Ti}_{6} \mathrm{Al}_{4} \mathrm{~V}$ substrate. The
MAO intermediate layer improved the load-bearing capacity and tribological properties of the DLC coatings markedly because it decreased the mechanical incompatibility between the soft substrate and hard coating [23].

\subsection{Results of Tribo-corrosion Test}

Tribo-corrosion tests were carried out in order to research the tribo-corrosion behavior emerging with the synergic effect of the wear and corrosion of untreated and oxidized samples using the MAO process at different frequencies. First of all, during the tribo-corrosion experiments, the open circuit potential (OCP) values under frictionless conditions in a $3.5 \% \mathrm{NaCl}$ solution have been determined for the samples inside the tribo-corrosion cell. The value in the "Potential-Time Curve" that continued in a stable position has been observed in the form of OCP. The stable structure of potential values after a certain value shows that the electrochemical events occurring on the surface are also stable. After the OCP values have been determined, the potential-time curves achieved in order to specify the OCP under friction, and frictionless conditions are given in Fig. 11. These OCP determined under pin-on-disk conditions evidence a complex potential reflecting the combined situation between the worn and unworn surfaces on the basis of the literature; it is known that a galvanic couple is formed between the corroded and non-corroded surfaces under these conditions [24]. Important parameters affect the existence of the OCP. These parameters consist of the open circuit potentials of materials found in the worn and unworn areas, the proportion of the worn area with respect to the unworn area, and the mechanism and kinetics of the reactions formed to rate the anodic and cathodic zones of the unworn areas [31]. As seen in Fig. 11, the OCP values of the samples remain at a stable value before the friction starts and decreases immediately after the friction commences. These values continue to remain stable under friction conditions, increase immediately after friction is eliminated, and then continue at a stable rate. It has been seen that the OCP values of uncoated samples are at a lower value when compared to the coated samples. The underlying reason in the low rate of the OCP in uncoated samples is the easy breaking of the passive oxide layer existing on the surface under friction conditions and the direct contact of the corrosion solution with the substrate [32-35]. During sliding, the friction coefficient was approximately 0.37 (Fig. 11a). Fluctuations have been observed in the OCP values, which are determined especially under friction. This situation causes some fluctuations in the potential values of the $\mathrm{A}_{2}{ }_{2} \mathrm{O}_{3}$ pin bearing during its movement inside the wear track. These fluctuations are due to the constant breakage and re-forming of the passive oxide layer on the surface. The ratio of worn and 

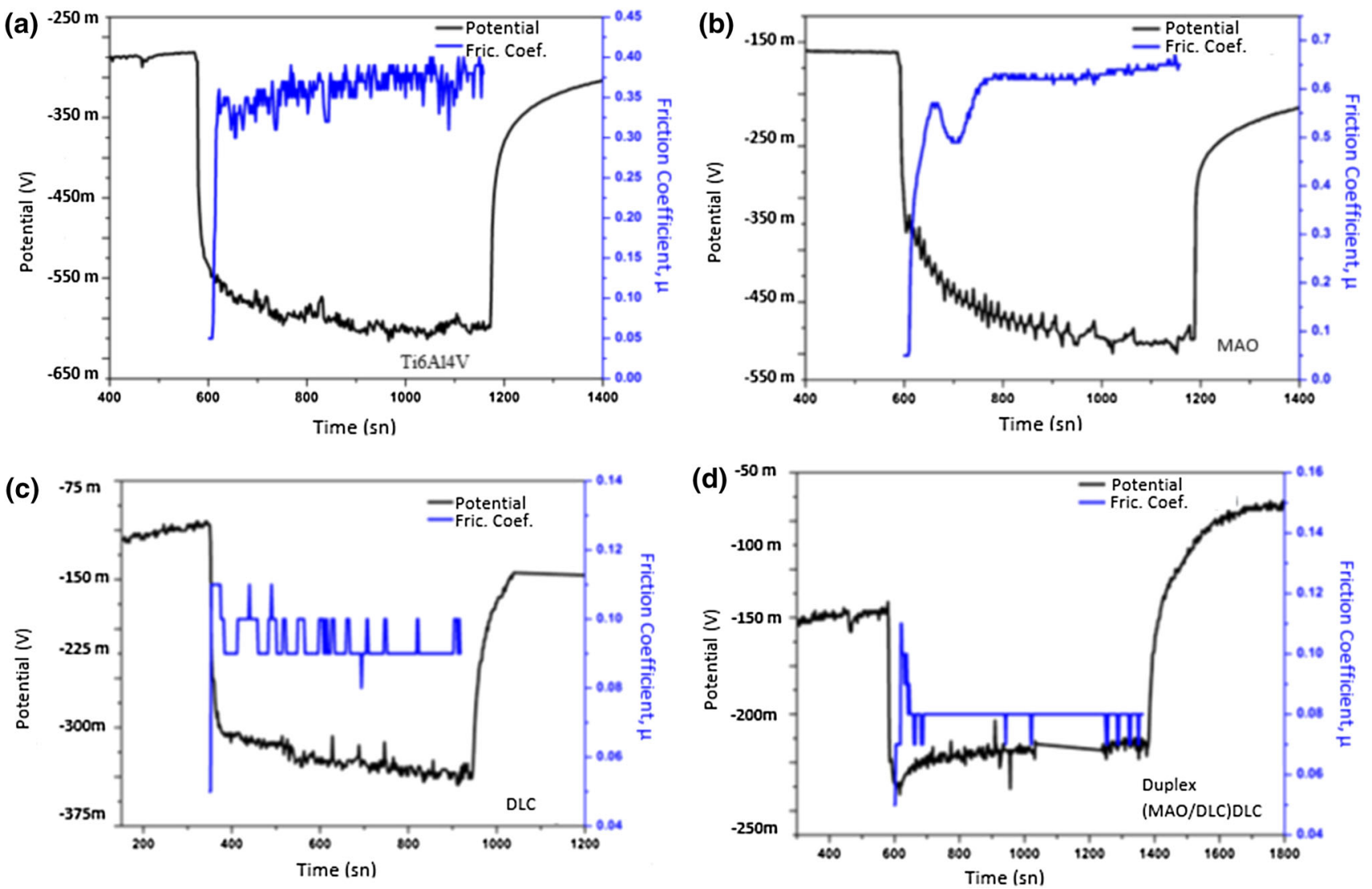

Fig. 11 Coefficient of friction and OCP curves a uncoated, b MAO coated, $\mathbf{c}$ DLC coated, and d duplex (MAO/DLC) coated

unworn areas, in particular, if the extent of the worn area increases, the OCP of the samples will shift depending on the controlling electrochemical processes, being either anodic (e.g., the dissolution of the metal) or the cathodic reaction (e.g., the reduction of hydrogen or dissolved oxygen) [32]. On the other hand, the OCP values of the coated sample exhibited more noble values than the uncoated samples. One of the reasons that the coated sample's potential value exhibits more noble values than the uncoated samples is the reduced cathodic reaction speed caused by the surface coating. It is observed that the OCP values that are determined under friction condition had fluctuations. In this case, $\mathrm{Al}_{2} \mathrm{O}_{3}$ ball movement causes some fluctuations at potential value in the wear track. These fluctuations are due to constantly breaking and reoccurring passive oxide layer on the surface. It is seen in Fig. 11 that the OCP values obtained were $-600,-450$, -310 , and $-220 \mathrm{mV}$ for the $\mathrm{Ti}_{6} \mathrm{Al}_{4} \mathrm{~V}$ alloy substrate, the MAO-coated samples, DLC-coated samples, and MAO/ DLC duplex-coated samples, respectively. The drop in the OCP value for the $\mathrm{Ti}_{6} \mathrm{Al}_{4} \mathrm{~V}$ alloy substrate was more than the coated samples. It was observed that for the uncoated samples, the OCP values decreased at the beginning of the wear test, the friction coefficient minimum increased, and then the increase in the friction and coefficient continued remaining stable until the end of the tribo-corrosion test. However, there has been a different behavior on all coated samples. The friction coefficient values increased immediately after the beginning of the experiment followed by a reduction from the first half of the test and then there have been relatively stable coefficient of friction values. In addition, simultaneous changes can be observed between the coefficient of friction and the OCP curves in Fig. 11. Therefore, in areas where the friction coefficient is stable, the OCP curves are seen to be relatively stable too.

Figure 12 shows the potentiostatic tribo-corrosion behavior of both the coated samples and uncoated sample immersed in $3.5 \% \mathrm{NaCl}$ solution before, during, and after rubbing against an $\mathrm{Al}_{2} \mathrm{O}_{3}$ ball. It is known that the current density values increased with the wear test starting. This wear test caused the abrasive effect under the tribo-corrosion conditions on the metals, which are passivation [64, 65]. It was seen that the current density values increased on the uncoated samples. However, the current density values decreased on the all coated samples (Fig. 12). Mathew et al. referred this situation in their study. They indicated that the wear and the corrosion products gathered up the contact zone, so this product played the barrier role and it caused a 

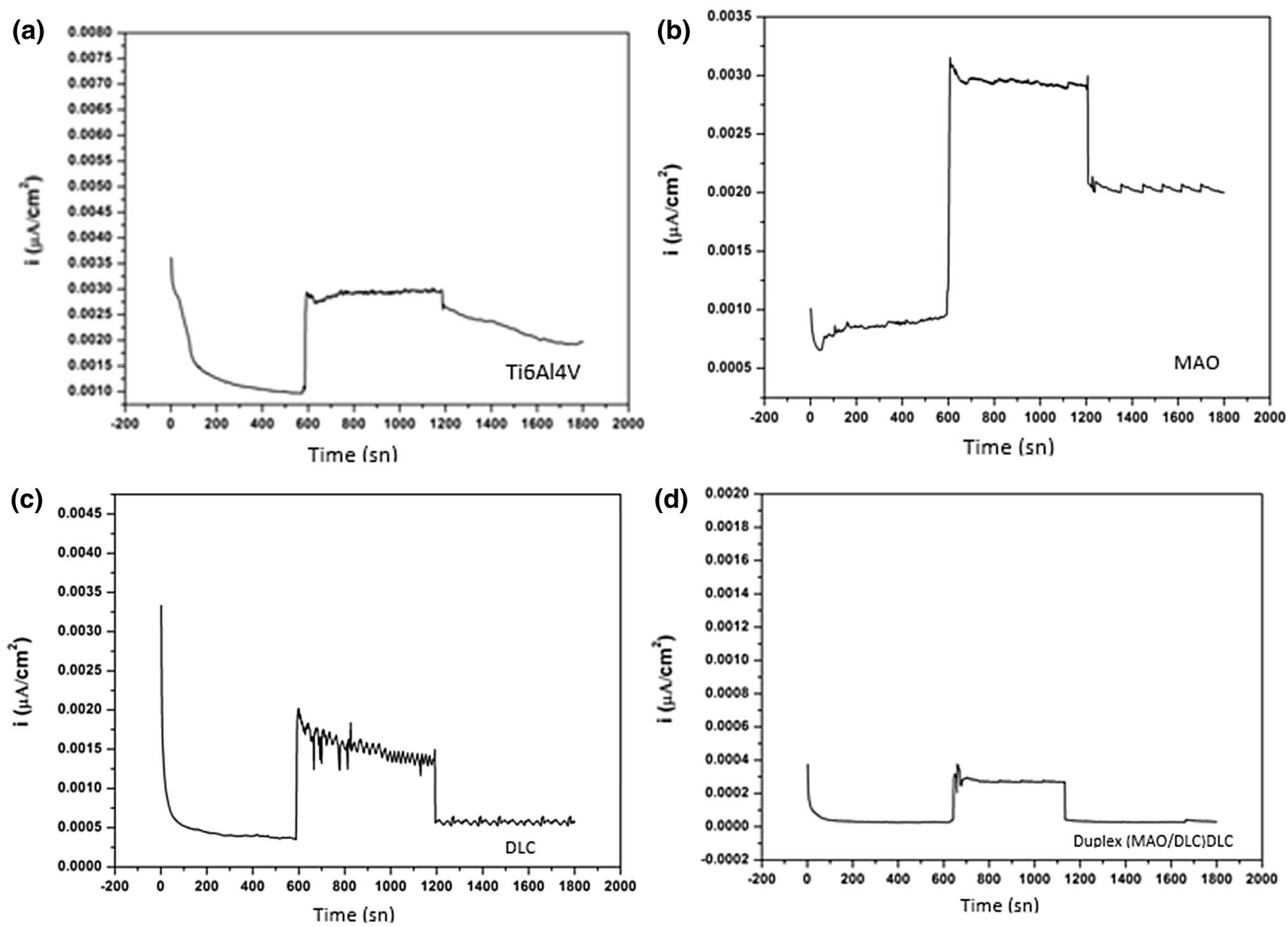

Fig. 12 Potentiostatic tribo-corrosion behavior of samples a uncoated, b MAO coated, c DLC coated, and d duplex (MAO/DLC) coated

decrease in the current density. In this study, there is the same situation with the literature. The current density value decreased by the effects of wear and corrosion products. In Fig. 12, it is seen that if the wear condition continues, the wear and corrosion products cause abrasive effects and thus the current density value increases at some point. When the wear conditions stopped, the products that are removed from the substrate and corrosion products caused the repassivisation on the surface and it was observed that the protective layer was formed on the surface, and thus it was determined that the current density value decreased again.

\section{Conclusion}

The following conclusions can be derived from the above results and discussion:

- $\mathrm{TiO}_{2}$ coating was successfully prepared on the $\mathrm{Ti}_{6} \mathrm{Al}_{4} \mathrm{~V}$ alloys surface using the MAO process. The oxide film has a thicker and greater homogeneous thickness of approximately $5 \mu \mathrm{m}$, and contains smaller porosity.
- The dense microstructure is an important factor for the hardness. This causes an increase in the wear resistance.

- Duplex coatings were uniform, compact, smooth, and dense as the DLC films that were directly coated onto the substrate.

- The MAO/DLC duplex coated has the hardest hardness value.

- The high substrate voltage caused the high compressive stress and high frequency increased the ionized particles flow acceleration, and thus these two parameters' sputtering pressure to be effective considering the high hardness of DLC MAO/DLC duplex coating growth is provided.

- DLC coating and MAO/DLC duplex coatings exhibited the passivation tendency behavior, they have high corrosion potential values and low corrosion current values. The increase in the corrosion resistance on the DLC coating was explained by electron reduction.

- Increase in the corrosion resistance can be associated with the decrease in the electron conductivity.

- The corrosion current and the highest value of the corrosion potential occur in the samples that are MAO/ DLC duplex coated. The corrosion current densities 
$\left(I_{\text {corr }}\right)$ are $5 \times 10^{-6} \mathrm{~A} / \mathrm{cm}^{2}$ for the $\mathrm{Ti}_{6} \mathrm{Al}_{4} \mathrm{~V}$ substrate, $10 \times 10^{-9}, 1 \times 10^{-9}$, and $5 \times 10^{-9} \mathrm{~A} / \mathrm{cm}^{2}$ for the coated samples, MAO, DLC, and MAO/DLC, respectively. The corrosion potentials $\left(E_{\text {corr }}\right)$ are $-700 \mathrm{mV}$ for the $\mathrm{Ti}_{6} \mathrm{Al}_{4} \mathrm{~V}$ substrate, $-200,50$, and $250 \mathrm{mV}$ for the coated samples MAO, DLC, and MAO/DLC, respectively. It was observed that the corrosion potential of the coating rose to more respectable values as compared to the substrate.

- The reason of the high and unstable coefficient of friction until around $100 \mathrm{~s}$ is the amorphous loose layer of the MAO coatings. Wearing the amorphous loose layer immediately, the layer called functional main layer occurred and thus it caused the stable friction coefficient.

- The friction accelerated the transformation from $s p^{3}$ to $s p^{2}$ and thus, it created a transfer film on the DLC surfacelike graphite and this film participated in lubrication.

- The highest value of the wear resistant occurs in the samples that are MAO/DLC duplex coated.

- The current density values increased on the uncoated samples. However, the current density values decreased on all coated samples.

- The OCP values of the coated sample exhibited more noble values than the uncoated samples. One of the reasons that the coated sample's potential value exhibits more noble values than the uncoated samples is the reduced cathodic reaction speed caused by the surface coating.

- The highest value of the tribo-corrosion resistant occurs in the samples that are MAO/DLC duplex coated.

Acknowledgments The authors would like to thank the Faculty of Engineering, Department of Mechanical Engineering at Ataturk University and the Scientific and Technological Research Council of Turkey (TUBITAK) for funding the project by Grant No. MAG 109 M 050.

\section{References}

1. Williams WL (1970) The effect of beta processing on properties of titanium alloys. In: The science, technology and application of titaniumthe science, technology and application of titanium. Proceedings of international conference on titanium, Pergamon Press, London

2. Eylon D, Seagle SR (2000) Advances in titanium technology: an overview. Keikinzoku 50(8):359-370

3. Budinski KG (1991) Tribological properties of titanium alloys. Wear 151:203-217

4. Ceschini L, Lanzoni E, Martini C, Prandstraller D, Sambogna G (2008) Comparison of dry sliding friction and wear of $\mathrm{Ti}_{6} \mathrm{Al}_{4-}$ Valloy treated by plasma electrolytic oxidation and PVD coating. Wear 264:86

5. Liu C, Bi Q, Matthews A (2003) Corrosion resistance of multilayered PAPVD TiN and CrN coatings. Surf Coat Technol 163-164:597
6. Avelar-Batista JC, Spain E, Housden J, Fuentes GG, Rodriguez R, Montala F, Carreras LJ, Tate TJ (2005) Effect of coating thickness and deposition methods on the stripping rate of $\mathrm{Cr}-\mathrm{N}$ coatings. Surf Coat Technol 200:1842-1848

7. Martini C, Ceschini L (2011) A comparative study of the tribological behaviour of PVD coatings on the Ti- 6Al-4V alloy. Tribol Int 44(3):297-308

8. Grögler T, Plewa O, Rosiwal SM, Singer RF (1998) CVD diamond films as protective coatings on titanium alloys. Int J Refract Metal Hard Mater 16(3):217

9. Balcaen Y, Radutoiu N, Alexis J, Beguin JD, Lacroix L, Samelor D, Vahlas C (2011) Mechanical and barrier properties of MOCVD processed alumina coatings on $\mathrm{Ti}_{6} \mathrm{Al}_{4} \mathrm{~V}$ titanium alloy. Surf Coat Technol 206(7):1684

10. Johns SM, Bell T, Samandi M, Collins GA (1996) Wear resistance of plasma immersion ion implanted Ti-6Al-4V. Surf Coat Technol 85(1-2):7

11. Chen TJ, Chiou YC, Lee RT (2009) Grinding characteristics of diamond film using composite electro-plating in-process sharpening method. Int J Mach Tools Manuf 49(6):470-477

12. Berger LM (2015) Application of hardmetals as thermal spray coatings. Int J Refract Metal Hard Mater 49:350-364

13. James Pickles CS, Coad EJ, Jilbert GH, Field JE (1995) The erosive behaviour of diamond. In: Bogy DB, Donley MS,Drory MD, Field JE (eds) Symposium I-Mechanical behavior of diamond and other forms of carbon. MRS Spring Meeting, vol 383. MRS, Pittsburgh, pp 327-338

14. Balcaen Y, Radutoiu N, Alexis J, Beguin JD, Lacroix L, Samelor D, Vahlas C (2011) Mechanical and barrier properties of MOCVD processed alumina coatings on $\mathrm{Ti}_{6} \mathrm{Al}_{4} \mathrm{~V}$ titanium alloy. Surf Coat Technol 206(7):1684

15. Johns SM, Bell T, Samandi M, Collins GA (1996) Wear resistance of plasma immersion ion implanted Ti6Al4V. Surf Coat Technol 85(1-2):7-14

16. Xue W, Deng Z, Chen R, Zhang T (2000) Growth regularity of ceramic coatings formed by microarc oxidation on $\mathrm{Al}-\mathrm{Cu}-\mathrm{Mg}$ alloy. Thin Solid Films 372:114

17. Sun X, Jiang Z, Xin S, Yao Z (2005) Composition and mechanical properties of hard ceramic coating containing $\alpha$ $\mathrm{A} 12 \mathrm{O} 3$ produced by microarc oxidation on Ti-6Al-4V alloy. Thin Solid Films 471:194-199

18. Yerokhin AL, Leyland A, Matthews A (2002) Kinetic aspects of aluminium titanate layer formation on titanium alloys by plasma electrolytic oxidation. Appl Surf Sci 200:172-184

19. Xue W, Wang C, Chen R, Deng Z (2002) Structure and properties characterization of ceramic coatings produced on $\mathrm{Ti}-6 \mathrm{Al}-4 \mathrm{~V}$ alloy by microarc oxidation in aluminate solution. Mater Lett 52(6):435-441

20. Zhu MH, Cai ZB, Lin XZ, Ren PD, Tan J, Zhou ZR (2007) Fretting wear behaviour of ceramic coating prepared by microarc oxidation on Al-Si alloy. Wear 263:472-480

21. Zhang XL, Jiang ZhH, Yao ZhP, Wu ZhD (2010) Electrochemical study of growth behaviour of plasma electrolytic oxidation coating on Ti6Al4V: effects of the additive. Corros Sci 52:3465-3473

22. Vangolu Y, Arslan E, Totik Y, Demirci EE, Alsaran A (2010) Optimization of the coating parameters for micro-arc oxidation of Cp-Ti. Surf Coat Technol 205(6):1764-1773

23. Arslan E, Totik Y, Demirci EE, Efeoglu I (2013) Wear and adhesion resistance of duplex coatings deposited on $\mathrm{Ti}_{6} \mathrm{Al}_{4} \mathrm{~V}$ alloy using MAO and CFUBMS. Surf Coat Technol 214:1-7

24. Demirci EE, Arslan E, Ezirmik KV, Baran Ö, Totik Y, Efeoglu İ (2013) Investigation of wear, corrosion and tribocorrosion properties of AZ91 Mg alloy coated by micro arc oxidation process in the different electrolyte solutions. Thin Solid Films 528:116-122 
25. Leng YX, Chen JY, Yang P, Sun H, Wan GJ, Huang N (2003) Mechanical properties and platelet adhesion behavior of diamond-like carbon films synthesized by pulsed vacuum arc plasma deposition. Surf Sci 531(2):177-184

26. Bonetti LF, Capote G, Santos LV, Corat EJ, Trava-Airoldi VJ (2006) Adhesion studies of diamond-like carbon films deposited on $\mathrm{Ti}_{6} \mathrm{Al}_{4} \mathrm{~V}$ substrate with a silicon interlayer. Thin Solid Films 515(1):375-379

27. Zhang ZX, Dong H, Bell T, Xu BS (2008) The effect of deep-case oxygen hardening on the tribological behaviour of a-C: H DLC coatings on $\mathrm{Ti}_{6} \mathrm{Al}_{4} \mathrm{~V}$ alloy. $\mathrm{J}$ Alloy Compd 464(1-2):519-525

28. Dearnaley G, Arps JH (2005) Biomedical applications of diamond-like carbon (DLC) coatings: a review. Surf Coat Technol 200:2518-2524

29. Zhang S, Bui XL, Fu Y (2003) Magnetron sputtered hard a-C coatings of very high toughness". Surf Coat Technol 167:137-142

30. Myung HS, Park YS, Jung MJ, Hong B, Han JG (2004) Synthesis and mechanical properties of amorphous carbon films by closedfield unbalanced magnetron sputtering. Mater Lett 58:1513-1516

31. Teer DG, UK Patent No. 2258 343, USA Patent No. 5554 519, European Patent No. 0521045

32. Monaghan DP, Teer DG, Logan PA, Efeoglu I, Arnell RD (1993) Deposition of wear resistant coatings based on diamond like carbon by unbalanced magnetron sputtering. Surf Coat Technol 60:525-530

33. Kelly PJ, Arnell RD (1998) The determination of the currentvoltage characteristics of a closed-field unbalanced magnetron sputtering system. Surf Coat Technol 98:1370-1376

34. Bell T, Dong H, Sun Y (1998) Realising the potential of duplex surface engineering. Tribol Int 31:127-137

35. Nie X, Leyland A, Matthews A (2000) Deposition of layered bioceramic hydroxyapatite/TiO2 coatings on titanium alloys using a hybrid technique of micro-arc oxidation and electrophoresis. Surf Coat Technol 125:407-414

36. Ma S, Xu K, Jie W (2004) Wear behavior of the surface of Ti$6 \mathrm{Al}-4 \mathrm{~V}$ alloy modified by treating with a pulsed d.c. plasmaduplex process. Surf Coat Technol 185:205-209

37. Wang YM, Jiang BL, Lei TQ, Guo LX (2005) Microarc oxidation and spraying graphite duplex coating formed on titanium alloy for antifriction purpose. Appl Surf Sci 246:214-221

38. Liang J, Wang P, Hu L, Hao J (2007) Tribological properties of duplex MAO/DLC coatings on magnesium alloy using combined microarc oxidation and filtered cathodic arc deposition. Mater Sci Eng A 454-455:164-169

39. Long LH, Young KM, Hae WK, Young KW, Hyoun KE, Seong HJ, Jai KY (2004) Improved biological performance of Ti implants due to surface modification by micro-arc oxidation. Biomaterials 25:2867-2875

40. Han Y, Hong SH, Xu K (2002) Synthesis of nanocrystalline titania films by micro-arc oxidation. Mater Lett 56:744-747

41. Balon F, Stolojan V, Silva SRP, Michalka M, Kromka A (2005) Diamond-like carbon thin films for high-temperature applications prepared by filtered pulsed laser deposition. Vacuum 80:163

42. Ossi PM, Bottani CE, Miotello A (2005) Pulsed-laser deposition of carbon, from DLC to cluster-assembled films. Thin Solid Films 482:2-8

43. Li Z, Meng F, Liu X (2011) Wettability control by DLC coated nanowire topography. Nanotechnology 22(135302):8

44. Baszkiewicz J, Krupa D, Mizera J, Sobczak WJ, Bilinski A (2005) Corrosion resistance of the surface layers formed on titanium by plasma electrolytic oxidation and hydrothermal treatment. Vacumm 78:143-147

45. Yerokhin AL, Nie X, Leyland A, Matthews A, Dowey SJ (1999) Plasma electrolysis for surface engineering. Surf Coat Technol 122:73-93
46. Neto CLB, Silva MAM, Alves C (2009) In vitro study of cell behaviour on plasma surface modified titanium. Surf Eng 25:146-150

47. Ishizawa H, Ogino M (1995) Formation and characterization of anodic titanium oxide films containing $\mathrm{Ca}$ and $\mathrm{P}$. J Biomed Mater Res 29:65-72

48. Han Y, Hong SH, Xu K (2002) Synthesis of nanocrystalline titania films by micro-arc oxidation. Mater Lett 56:744-747

49. Han Y, Hong HS, Xu KW (2002) Porous nanocrystalline titania films by plasma electrolytic oxidation. Surf Coat Technol 154:314-318

50. Oonishi H, Fujita H, Itoh S et al (2002) Surface analysis on retrieved ceramic total knee prosthesis. Key Eng Mater 218-220: 499-502

51. Ma F, Li G, Li H, Mab H, Cai X (2002) Diamond-like carbon gradient film prepared by unbalanced magnetron sputtering and plasma immersion ion implantation hybrid technique. Mater Lett 57:82-86

52. Arslan E, Totik Y, Demirci EE, Vangölü Y, Alsaran A, Efeoglu I (2009) High temperature wear behavior of aluminum oxide layers produced by AC micro arc oxidation. Surf Coat Technol 204:829-833

53. Khaselev O, Weiss D, Yahalom J (2001) Structure and composition of anodic films formed on binary $\mathrm{Mg}-\mathrm{Al}$ alloys in $\mathrm{KOH}-$ aluminate solutions under continuous sparking. Corros Sci 43:1295-1307

54. Dorner A, Schürer C, Reisel G, Irmer G, Seidel O, Müller E (2001) Diamond-like carbon-coated Ti6Al4V: influence of the coating thickness on the structure and the abrasive wear resistance. Wear 249(5-6):489-497

55. Porfenov EV, Yerokhin AL, Matthews A (2007) Frequency response studies for the plasma electrolytic oxidation process. Surf Coat Technol 201:8661-8670

56. Bewinlogua K, Wittorf R, Thomsen H, Weber M (2004) DLC based coatings prepared by reactive dc magnetron sputtering. Thin Solid Films 447:142-147

57. Martini C, Ceschini L, Tarterini F, Paillard JM, Curran JA (2010) PEO layers obtained from mixed aluminate-phosphate baths on Ti-6Al-4V: dry sliding behaviour and influence of a PTFE topcoat. Wear 269:747-756

58. Fei C, Hai Z, Chen C, Yangjian X (2009) Study on the tribological performance of ceramic coatings on titanium alloy surfaces obtained through microarc oxidation. Prog Org Coat 64:264-267

59. Michler T, Grischke M, Traus I, Bewilogua K, Dimigen H (1998) DLC films deposited by bipolar pulsed DC PACVD. Diam Relat Mater 7:459-462

60. Liu Y, Meletis EI (2002) Tribological behavior of DLC coatings with functionally gradient interfaces. Surf Coat Technol 153(2-3): 178-183

61. Gupta P, Tenhundfeld G, Daigle EO, Ryabkov D (2007) Electrolytic plasma technology: science and engineering-an overview. Surf Coat Technol 201:8746-8760

62. Chen F, Zhou H, Yao B et al (2006) Study on the tribological behavior of micro-arc oxidation ceramic coating on magnesium alloy surfaces. Rare Met Mater Eng 35(5):806-810

63. Jiang SW, Yin GF, Zheng CQ et al (2001) Friction and wear behavior of DLC gradient film on $\mathrm{Ti}_{6} \mathrm{Al}_{4} \mathrm{~V}$ alloy substrate in sliding against ultra-high molecular weight polyethylene. Tribology 21(3): 167-171

64. Ferreira SC, Sequeira PD, Watanabe Y, Ariza E, Rocha LA (2011) Microstructural characterization and tribo-corrosion behaviour of $\mathrm{Al} / \mathrm{Al}_{3} \mathrm{Ti}$ and $\mathrm{Al} / \mathrm{Al}_{3} \mathrm{Zr}$ FGMs. Wear 270:806-814

65. Mischler S (2008) Triboelectrochemical techniques and interpretation methods in tribo-corrosion: a comparative evaluation. Tribol Int 41:573-583 